\title{
Metaplasia of renal glomerular capsular epithelium
}

\author{
DONALD J. MACPHERSON ${ }^{1}$
}

From the Department of Pathology, Hackensack Hospital, Hackensack, New Jersey, U.S.A.

SYNOPSIS Metaplastic changes in the renal glomerular epithelium is an unusual lesion. Only three other cases have been collected from the literature. This case is unique in that there was no associated liver disease.

\section{CASE REPORT}

A 74-year-old woman was admitted to hospital in a semi-stuperous state. Past history showed that she had had a radical mastectomy two years previously for carcinoma of the breast. At the time of operation no lymph node involvement was demonstrated. During the three years before her final admission she had three other periods in hospital: in the first two the illness was diagnosed as acute pancreatitis, only the first of which was substantiated by raised blood amylase determinations.

'Present address: Valley Hospital, Ridgewood, New Jersey, U.S.A.

Received for publication 6 February 1963.
The third admission, which took place only seven weeks before her final admission, was for marked polydypsia and polyuria. A clinical diagnosis of diabetes insipidus secondary to pituitary metastases was made at that time.

During the final admission her blood pressure remained normal. The left pupil was described as slightly larger than the right. Slight nuchal rigidity was noted at the time of admission. Examination of blood showed haemoglobin $15.6 \mathrm{~g}$. \%, white blood count 11,500 per c. mm. (88\% neutrophils and $12 \%$ lymphocytes), sugar $112 \mathrm{mg}$. $\%$, non-protein nitrogen $45 \mathrm{mg}$. \%, alkaline phosphatase 5.8 Bodansky units, chloride $109 \mathrm{mEq} . / 1$., sodium $146 \mathrm{mEq} . / 1$., potassium $3.7 \mathrm{mEq} . / 1$., and $\mathrm{CO}_{2}$ content 53 vol. $\%$. Urine analysis showed $p \mathrm{H} 5 \cdot 0$, specific gravity

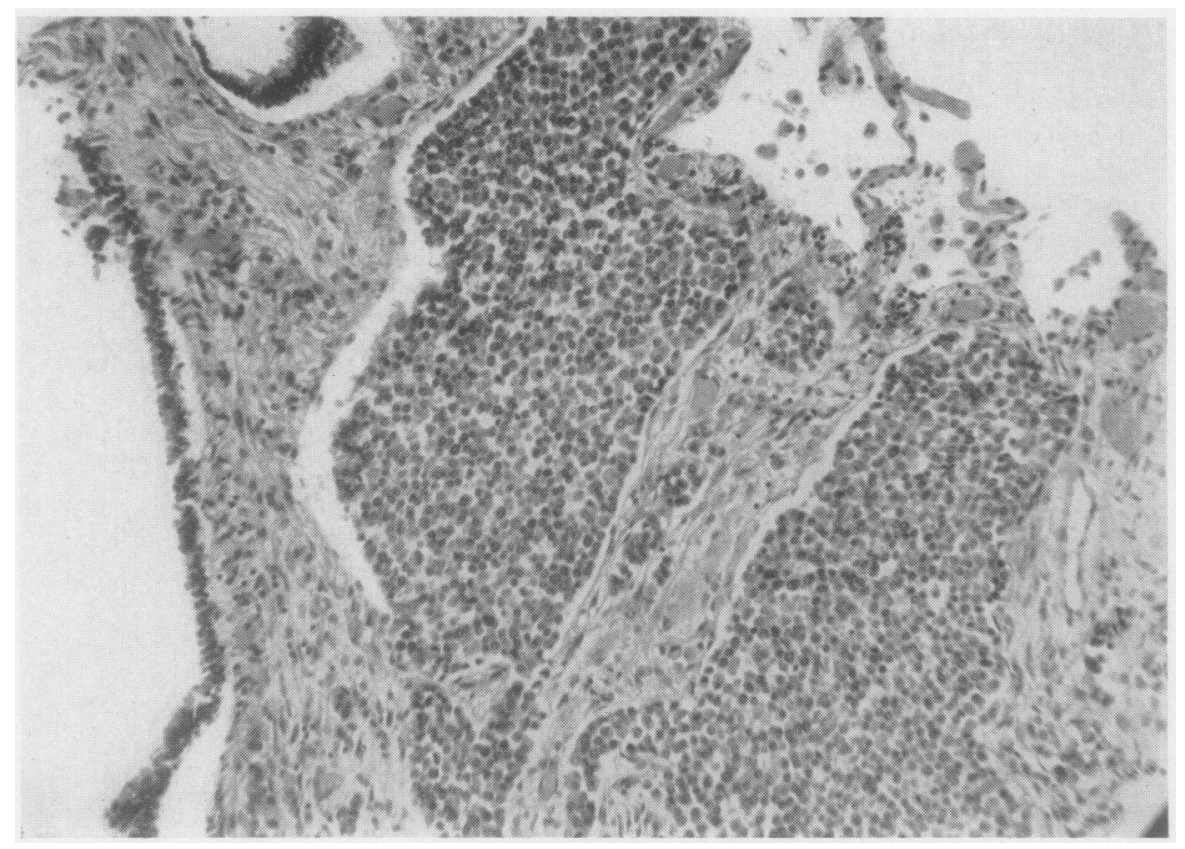

FIG. 1. Metastatic carcinoma in lung compatible with a primary origin in breast $(\times 137)$. 


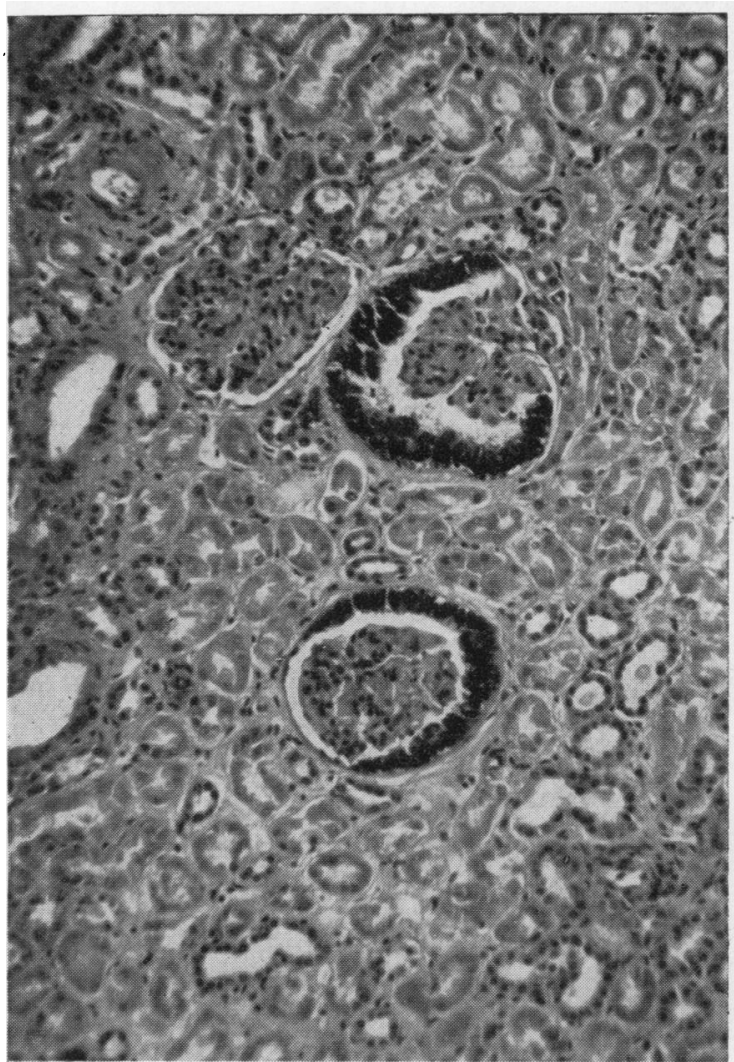

A

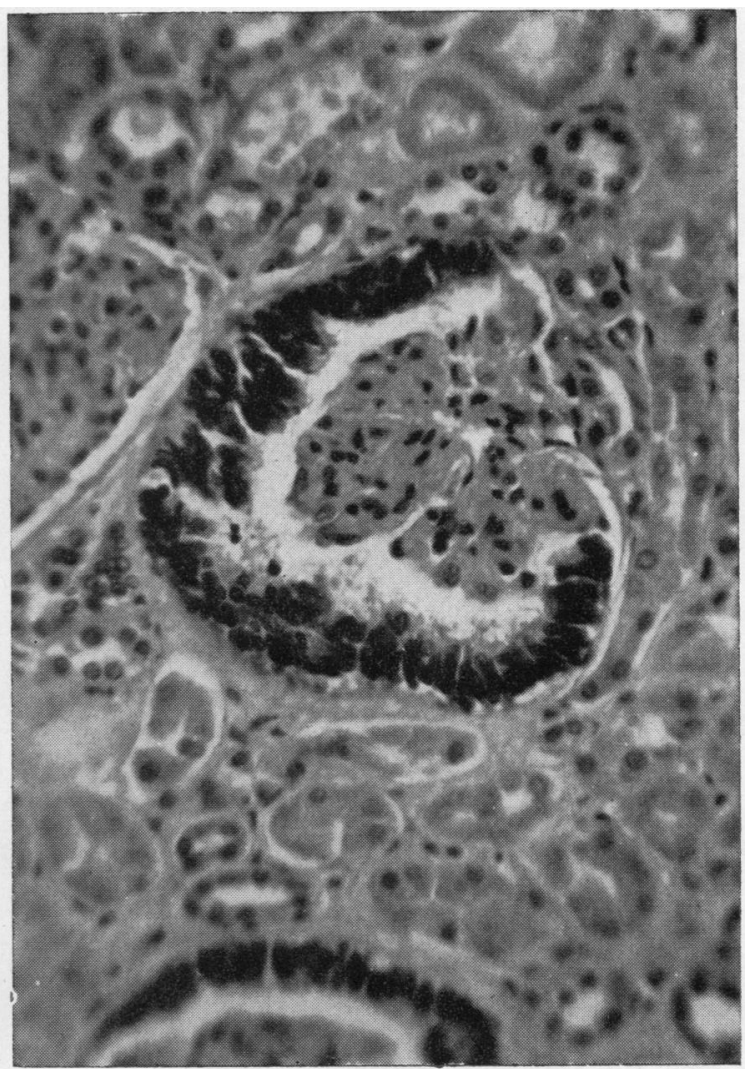

B

FIG. 2. Metaplasia of renal glomerular capsular epithelium. A, note that only one glomerulus in the field is not involved by the metaplastic process $(\times 137)$. B, higher magnification showing the prominent parietal layer $(\times 344)$.

1.015 , sugar $1+$, albumin $1+$, acetone negative, and 15 to 30 white blood cells per high-power field.

Treatment included pitressin, prednisone, dilantin, and pituitrin S. During the first four days in hospital the patient remained only partially responsive. On the fifth day she developed marked nuchal rigidity and refused all oral medication. Spinal fluid findings at that time included 3 white blood cells per c. mm., protein $62 \mathrm{mg} . \%$, and sugar $80 \mathrm{mg}$. \%. Culture of the spinal fluid showed no growth. The blood non-protein nitrogen level rose gradually to $100 \mathrm{mg}$. $\%$ and the patient died on the twelfth hospital day.

\section{NECROPSY}

The examination was done 11 hours after death. The body was that of a cachectic elderly women. The pleural and peritoneal cavities contained large amounts of semisanguinous fluid. The brain, posterior lobe of the pituitary, heart, lungs, pancreas, adrenals, omentum, ovaries, and Fallopian tubes all contained gray tumour tissue. The liver 6 showed only evidence of congestion. The kidneys were normal in weight and showed no evidence of metastases.

Microscopic examination showed that the tumour tissue was probably secondary carcinoma from the primary breast carcinoma, characterized by cords of cells showing pleomorphism, increased nuclear chromatin, prominent mitoses, and an increased nuclear cytoplasmic ratio (Fig. 1). Unfortunately the slides of the orisinal breast carcinoma were not available for review.

Sections of each kidney showed that about $70 \%$ of the glomeruli exhibited a marked thickening of the parietal layer of Bowman's capsule due to the numerous stratified columnar cells showing very prominent basophilic nuclei and pale cytoplasm (Fig. 2). No mitoses were seen. Similar cells also involved some of the proximal convoluted tubules. The glomeruli and the visceral layers of Bowman's capsule were not involved. 
TABLE I

\begin{tabular}{|c|c|c|c|c|c|}
\hline SUMMARY OF & $\begin{array}{c}\text { REPORTED } \\
\text { Age }\end{array}$ & $\begin{array}{l}\text { CASES OF } \\
\text { Sex }\end{array}$ & $\begin{array}{l}\text { METAPLASIA OF } \\
\text { Site of Primary } \\
\text { Tumour }\end{array}$ & $\begin{array}{l}\text { RENAL GLOMERULAR CAPSULAR } \\
\text { Metastatic Sites }\end{array}$ & $\begin{array}{l}\text { EPITHELIUM } \\
\text { Urine Analysis }\end{array}$ \\
\hline Eisen (1946) & $54 \mathrm{yr}$. & $\mathbf{F}$ & Gall bladder & $\begin{array}{l}\text { Common bile duct, liver, } \\
\text { hepatic lymph nodes, lung }\end{array}$ & $\begin{array}{l}\text { Growth of Streptococcus } \\
\text { viridans and Staphylococcus } \\
\text { albicans }\end{array}$ \\
\hline Chappell and Phillips (1950) & $16 \mathrm{yr}$. & $\mathbf{M}$ & Adrenal gland & Liver, pleura & Normal \\
\hline Nachman (1962) & $6 \mathrm{mth}$. & $\mathbf{F}$ & Liver & Lung, bone marrow & $\begin{array}{l}4+\text { protein; many R.B.C.s } \\
\text { W.B.C.s }\end{array}$ \\
\hline
\end{tabular}

\section{DISCUSSION}

Eisen (1946) first described adenomatoid transformation of the glomerular capsular epithelium. The salient features of his case report and of two other case reports (Chappell and Phillips, 1950; Nachman, 1962) are listed in Table I. As in this case, each of these patients had a concurrent metastatic malignancy. Eisen wrote that the capsular changes represented a primary neoplastic change possibly due to excretion of some tumour-exciting agent, virus or chemical. Chappell noted that no tumour cells were present within the glomeruli even though he did indicate a histological resemblance of the capsular changes to the tumour. He suggested that in order to prove that the renal change was primary, it would be necessary to find a patient having this change in the kidney with no cancer elsewhere in the body. Nachman reported a possible relationship between the glomerular changes and liver disease, stating $\overrightarrow{\vec{\omega}}$ that his case and those of Eisen and Chappell all showed the liver to be involved by carcinoma, ? either primary or metastatic. Lack of histological $\vec{\sigma}$ similarity and of the usual changes in the urine $\omega$ tend to rule out the capsular changes as an atypical N form of glomerulonephritis (Nachman, 1962). Even 0

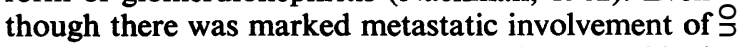
other organs, the liver in this case was intact and had a normal histology. There was no cellular similarity between the metastatic carcinoma and the changes $*$ in the kidney. The cause of this metaplastic change $\overrightarrow{\mathscr{C}}$ in Bowman's capsule remains unknown.

\section{REFERENCES}

Chappell, R. H., and Phillips, J. R. (1950). Arch. Path. (Chicago), $49,70$.

Eisen, H. N. (1946). Amer. J. Path., 22, 597.

Nachman, R. L. (1962), Arch. Path. (Chicago), 73, 48. 